\title{
ІНФОРМАЦІЯ
}

\section{ПЕРЕЛІК ЗАХИЩЕНИХ ДИСЕРТАЦІЙ У 2020 РОЦІ}

\author{
Дисертації, \\ захищені в спеціалізованій ученій раді К 26.001.49 \\ Київського національного університету імені Тараса Шевченка
}

Ващило Ольга Валеріївна "Методика навчання майбутніх інженерів-механіків англійського професійно орієнтованого монологічного мовлення" (13.00.02 - теорія та методика навчання (германські мови).

Дисертацію присвячено розв'язанню проблеми підвищення ефективності навчання майбутніх інженерів-механіків англійського професійно орієнтованого монологічного мовлення 3 використанням технології подкастингу.

У дисертації обгрунтовано доцільність розроблення методики навчання майбутніх інженерів-механіків професійно орієнтованого монологу-міркування, визначено підходи до навчання (комунікативно-діяльнісний та професійно орієнтований підходи), окреслено методичні принципи навчання та розглянуто шляхи їхньої реалізації, охарактеризовано дидактичні та методичні можливості сервісу подкастів; створено авторський сервіс подкастів на навчальній платформі Canvas; визначено критерії відбору англомовних автентичних подкастів та здійснено їх добір; визначено навички та уміння професійно орієнтованого монологуміркування; розроблено підсистему вправ із використанням технології подкастингу; створено модель навчання майбутніх інженерів-механіків професійно орієнтованого монологу-міркування; у межах моделі розглянуто особливості організації навчального процесу на етапах навчання; експериментальним шляхом доведено ефективність методики навчання; укладено методичні рекомендації з утілення розробленої методики у навчальний процес.

Ключові слова: професійно орієнтоване монологічне мовлення, професійно орієнтований монолог-міркування, інженер-механік, технологія подкастингу, автентичний подкаст, сервіс подкастів, принципи навчання, критерії добору подкастів, підсистема вправ.

Дзіман Ганна Михайлівна “Формування у майбутніх військових фахівців 3 інформаційних технологій англомовної компетентності в академічному письмі" (13.00.02 - теорія та методика навчання (германські мови).

Дисертацію присвячено теоретичному обгрунтуванню, розробці та експериментальній перевірці методики формування у майбутніх військових фахівців з інформаційних технологій англомовної компетентності в академічному письмі на основі методики змішаного навчання.

У дисертації охарактеризовано лінгвістичні основи навчання майбутніх військових фахівців 3 інформаційних технологій англомовного академічного письма; обгрунтовано мету і зміст формування англомовної компетентності в академічному письмі; окреслено принципи формування компетентності в академічному письмі; розглянуто особливості використання змішаного навчання із застосуванням хмарного сервісу Google Classroom; виділено принципи і критерії відбору навчального матеріалу для формування у майбутніх військових фахівців з інформаційних технологій англомовної компетентності в академічному письмі; розроблено підсистему вправ, створено модель організації навчання; експериментально перевірено ефективність розробленої методики.

Ключові слова: писемне мовлення, академічне мовлення, компетентність у письмі, змішане навчання, хмарні технології, майбутні військові фахівці з інформаційних технологій. 
Тулякова Катерина Робертівна “Методика навчання англомовного професійно оріснтованого монологічного мовлення майбутніх фахівців у сфері медіації та врегулювання конфліктів" (13.00.02 - теорія та методика навчання (германські мови).

Наукова новизна дослідження полягає у тому, що у ньому вперше теоретично обгрунтовано, розроблено й експериментально перевірено методику навчання англомовного професійно орієнтованого монологічного мовлення майбутніх фахівців у сфері медіації та врегулювання конфліктів, яка реалізується впродовж трьох етапів (інформативний, діяльнісно-пошуковий та презентаційний), із застосуванням комплексу вправ і завдань, що передбачають використання технології комунікативно-конфліктного моделювання у поєднанні з автентичними відеоматеріалами.

На підставі отриманих результатів сформульовано методичні рекомендації щодо навчання англомовного професійно орієнтованого монологічного мовлення майбутніх фахівців у сфері медіації та врегулювання конфліктів.

Ключові слова: англомовне професійно орієнтоване монологічне мовлення, майбутні фахівці у сфері медіації та врегулювання конфліктів, автентичні відеоматеріали, комплекс вправ, етапи навчання, технологія комунікативно-конфліктного моделювання.

Дибська Тетяна Сергіївна "Методика змішаного навчання усного японського мовлення майбутніх філологів” (13.00.02 - теорія та методика навчання (східні мови).

У дисертації теоретично обгрунтовано, практично розроблено та експериментально перевірено методику змішаного навчання усного японського мовлення студентів освітнього рівня “бакалавр”.

Обгрунтовано й розроблено підсистему завдань і вправ для навчання усного японського мовлення за системою змішаного навчання, що реалізується в межах чотирьох основних ("Face-to-Face Driver", модель почергового розподілу форм роботи, "зміна робочих зон" та “"перевернута аудиторія”) та трьох допоміжних (“Flex", “Online Lab”, “Self-Blend”) моделей.

Розроблено модель авторської методики (у двох варіантах - 3 використанням під час очних занять елементів мікронавчання (мікропошуку) та без них) навчання усного японського мовлення майбутніх філологів.

У ході експерименту встановлено ефективність авторської методики у цілому. Перевага моделей, де використовувався мікропошук, не підтвердилася. Однаково ефективними виявилися результати в групах, що навчалися за моделями з мікропошуком та без мікропошуку. Достовірність результатів експерименту було доведено за допомогою статистичного методу Манна-Уїтні. Сформульовано методичні рекомендації щодо змішаного навчання майбутніх філологів усного японського мовлення за авторською методикою.

Ключові слова: філологи-японісти, усне японське мовлення, змішане навчання, модель змішаного навчання, модель “Face-to-Face Driver", модель почергового розподілу форм роботи, модель “Зміна робочих зон”, модель "Перевернута аудиторія".

Голова ради - доктор пед. наук, професор Шовковий В. М. Член ради - доктор пед. наук, професор Черниш В. В. 


\title{
Дисертації, захищені в спеціалізованій ученій раді К 41.053.04 \\ Державного закладу "Південноукраӥнський національний педагогічний університет імені К. Д. Ушинського"
}

\begin{abstract}
Перелома Тетяна Сергіївна "Методика навчання майбутніх філологів фонетики китайської мови" (13.00.02 - теорія та методика навчання (східні мови)

У дисертації теоретично обгрунтовано, практично розроблено й експериментально перевірено методику навчання майбутніх філологів фонетики китайської мови.

У роботі схарактеризовано лінгвістичні особливості фонетики китайської мови та труднощі iii сприйняття і засвоєння носіями української мови. Обгрунтовано сутність фонетичної компетентності майбутніх філологів-синологів у складі таких компонентів, як: когнітивний, діяльнісний, соціокультурний, мотиваційно-ціннісний, навчально-стратегічний. Визначено лінгводидактичні засади формування китайськомовної фонетичної компетентності та ії етапи, а саме: набуття теоретичних знань, формування фонетичних навичок, інтегрування фонетичних навичок у практику мовлення. Відібрано мовний і мовленнсвий матеріал для навчання майбутніх філологів-синологів фонетики китайської мови. Розроблено підсистему вправ з формування фонетичної компетентності майбутніх філологів-синологів та спроєктовано модель організації цього процесу. Проведено експериментальну апробацію запропонованої методики та перевірено iï ефективність за такими критеріями, як: артикуляційна нормативність, орієнтаційно-смислова, комунікативна адекватність, рефлексивність, рівень сформованості навчальних стратегій. Уточнено зміст фонетичної компетентності майбутніх філологів-синологів. Подальшого розвитку набули критерії добору китайськомовного фонетичного матеріалу.

Ключові слова: філологи-синологи, фонетика китайської мови, використання інформаційних ресурсів, початковий рівень навчання китайської мови в університеті, китайськомовна фонетична компетентність, методика навчання фонетики китайської мови.
\end{abstract}

Сторожук Світлана Дмитрівна “Формування писемної комунікативної компетентності майбутніх викладачів англійської мови на основі просктних технологій $(13.00 .02-$ теорія та методика навчання" (германські мови)

Дисертацію присвячено теоретичному обгрунтуванню, практичній розробці та експериментальній перевірці методики формування писемної комунікативної компетентності майбутніх викладачів англійської мови на основі проєктних технологій.

У роботі визначено поняття “іншомовна писемна комунікативна компетентність” майбутніх викладачів англійської мови, що формується засобами проєктних технологій, і проаналізовано використання проєктних технологій для навчання англомовного письма студентів мовних ЗВО. Обгрунтувано методичні принципи та етапи навчання англомовного письма через використання проєктних технологій. Структуровано зміст навчання письма студентів-філологів на основі використання проєктних технологій. Розроблено методику навчання англомовного письма iз застосуванням проєктних технологій і систему вправ, яка відповідає чотирьом етапам навчання. Запропонована система вправ стала підгрунтям для розробки моделі навчання писемної комунікативної компетентності майбутніх викладачів англійської мови. Розроблена модель обгрунтовує послідовність навчальних дій, демонструє зміст процесу навчання. Проведено експериментальну апробацію запропонованої методики та перевірено її ефективність, визначено критерії оцінювання рівня сформованості комунікативної компетентності в писемному мовленні, проаналізовано результати експерименту, подано їх статистичну обробку. На основі отриманих результатів сформульовано методичні рекомендації для формування писемної комунікативної компетентності майбутніх викладачів англійської мови на основі проєктних технологій. 
Ключові слова: підготовка майбутніх викладачів англійської мови, навчання англомовного письма, іншомовна писемна комунікативна компетентність, проєктні технології, методичні принципи, зміст навчання, модель навчального процесу.

Антоненко Інна Іванівна “Методика формування компетентності у професійно оріснтованому англійському писемному мовленні майбутніх фахівців 3 видавничої справи та редагування" (13.00.02 - теорія та методика навчання (германські мови)

У дисертації теоретично обгрунтовано, практично розроблено й експериментально перевірено методику формування компетентності у професійно орієнтованому англійському писемному мовленні майбутніх фахівців з видавничої справи та редагування.

Обгрунтовано рівневий, компетентнісний та жанровий підходи до розвитку вмінь деталізованого письма; констатовано доцільність міждисциплінарної взаємодії та інтегрованого компетентнісного підходу, під яким розуміємо процесуальну інтеграцію іншомовної комунікативної і професійної компетентностей; виокремлено жанрову компетентність як передумову синергетичного ефекту в навчанні писемного мовлення фахівців з видавничої справи. Жанровий підхід полягає в розвитку вмінь продукувати тексти анонсів, інформаційних або рекламних повідомлень у змодельованих професійних ситуаціях. Підкреслено необхідність вивчення жанрів медіатекстів, що є важливим питанням сучасної лінгводидактики в аспекті розвитку медіаосвіти. Проведено аналіз комунікативно-прагматичної і лінгводидактичної характеристик інформаційних і рекламних текстів, що дало змогу обгрунтувати методичну типологію жанрів, на основі якої реалізується перехід від еліптичного до деталізованого письма. Виокремлені критерії відбору дали змогу обрати навчальний матеріал, лексичний і граматичний мінімуми та зразки текстів. У дослідженні подано розроблену систему вправ, що складається з чотирьох груп вправ, які виконуються на трьох етапах. Запропонована система вправ стала підгрунтям для розробки моделі навчання англійського професійно орієнтованого писемного мовлення. Розроблена модель обгрунтовує послідовність навчальних дій, демонструє динамічність професій навчання. Проведено експериментальну апробацію запропонованої методики та перевірено ії ефективність, визначено критерії оцінювання рівня сформованості компетентності в писемному мовленні, проаналізовано результати експерименту, подано їх статистичну обробку. Експериментальні дані підтвердили гіпотезу дослідження, що розроблена лінгводидактична модель й відповідна до неї методика навчання професійно орієнтованого англійського писемного мовлення $є$ ефективною. На основі отриманих результатів сформульовано методичні рекомендації для навчання професійно орієнтованого англійського писемного мовлення майбутніх фахівців $з$ видавничої справи та редагування.

Ключові слова: професійно орієнтоване англійське писемне мовлення, процесуальна інтеграція, компетентнісний підхід, іншомовна комунікативна компетентність, жанрова компетентність, навчання деталізованого письма, рекламна замітка.

Учений секретар ради - кандидат пед. наук, доцент Кордонова А.В.

\section{Дисертаціï, захищені в спеціалізованій ученій раді К 58.053.05 Тернопільського національного педагогічного університету імені Володимира Гнатюка}

Скріль Ірина Валентинівна “Формування професійно оріснтованої англомовної лексичної компетентності в говорінні у майбутніх фахівців готельно-ресторанної справи 3 використанням автентичних відеоматеріалів” (13.00.02 - теорія та методика навчання (германські мови) 
У роботі теоретично обгрунтовано та розроблено методику формування професійно орієнтованої англомовної лексичної компетентності в говорінні у майбутніх фахівців готельноресторанної справи з використанням автентичних відеоматеріалів. Розкрито сутність ключових понять дослідження, визначено структуру професійно орієнтованої англомовної лексичної компетентності в говорінні у майбутніх фахівців готельно-ресторанної справи. Відібрано підходи до формування професійно орієнтованої англомовної лексичної компетентності в говорінні у майбутніх фахівців готельно-ресторанної справи з використанням автентичних відеоматеріалів й обгрунтовано принципи цього процесу. Проаналізовано значний методичний потенціал автентичних відеоматеріалів як ефективного засобу формування професійно оріснтованої англомовної лексичної компетентності в говорінні у ситуаціях професійно орієнтованого усного спілкування. Сконструйовано зміст формування професійно орієнтованої англомовної лексичної компетентності в говорінні у майбутніх фахівців готельноресторанної справи, здійснено відбір лексичних одиниць та відеофонограм на основі визначених критеріїв. Окреслено етапи формування професійно орієнтованої англомовної лексичної компетентності в говорінні у таких фахівців та запропоновано відповідну підсистему вправ. Розроблено лінгводидактичну модель формування професійно орієнтованої англомовної лексичної компетентності в говорінні у майбутніх фахівців готельно-ресторанної справи з використанням автентичних відеоматеріалів. Обгрунтовано мету, завдання, гіпотезу, характер, етапи, хід методичного експерименту, висвітлено зміст експериментального навчання. Інтерпретовано отримані дані оцінювання рівнів сформованості цільової компетентності в учасників експерименту, укладено методичні рекомендації.

Ключові слова: майбутні фахівці готельно-ресторанної справи, професійно орієнтована англомовна лексична компетентність в говорінні, автентичні відеоматеріали, лексичні одиниці, терміни, ситуації професійно орієнтованого усного спілкування, етапи навчання, підсистема вправ.

Голова ради - доктор пед. наук, професор І. П. Задорожна 